Article

\title{
Mechanical Properties and Tensile Failure Analysis of Novel Bio-absorbable Mg-Zn-Cu and Mg-Zn-Se Alloys for Endovascular Applications
}

\section{Dharam Persaud-Sharma ${ }^{1, *}$, Noah Budiansky ${ }^{2}$ and Anthony J. McGoron ${ }^{3}$}

1 Department of Biomedical Engineering, Florida International University, Miami, FL 33199, USA

2 Exponent Failure Analysis Consultants, Natick, MA 01760, USA;

E-Mail: nbudiansky@exponent.com

3 Florida International University, Department of Biomedical Engineering, Miami, FL 33199, USA;

E-Mail: mcgorona@fiu.edu

* Author to whom correspondence should be addressed; E-Mail: dpers001@fiu.edu.

Received: 22 November 2012; in revised form: 11 December 2012 / Accepted: 17 December 2012 /

Published: 21 December 2012

\begin{abstract}
In this paper, the mechanical properties and tensile failure mechanism of two novel bio-absorbable as-cast $\mathrm{Mg}-\mathrm{Zn}-\mathrm{Se}$ and $\mathrm{Mg}-\mathrm{Zn}-\mathrm{Cu}$ alloys for endovascular medical applications are characterized. Alloys were manufactured using an ARC melting process and tested as-cast with compositions of $\mathrm{Mg}-\mathrm{Zn}-\mathrm{Se}$ and $\mathrm{Mg}-\mathrm{Zn}-\mathrm{Cu}$, being 98/1/1 wt.\% respectively. Nanoindentation testing conducted at room temperature was used to characterize the elastic modulus $(\mathrm{E})$ and surface hardness $(\mathrm{H})$ for both the bare alloys and the air formed oxide layer. As compared to currently available shape memory alloys and degradable as-cast alloys, these experimental alloys possess superior as-cast mechanical properties that can increase their biocompatibility, degradation kinetics, and the potential for medical device creation.
\end{abstract}

Keywords: $\mathrm{Mg}-\mathrm{Zn}-\mathrm{Se} ; \mathrm{Mg}-\mathrm{Zn}-\mathrm{Cu}$; magnesium alloys; fracture analysis; mechanical properties 


\section{Introduction}

Magnesium alloys present new opportunities for biomedical applications because of their high strength and lightweight properties with favorable biocompatibility [1]. Most endovascular stents currently available today are permanently implanted and made from corrosion resistant metals such as stainless steel, Nitinol, and cobalt-chromium alloys. A material's mechanical properties used for such purposes dictate its ability to withstand the device forming processes. Stents are widely used because they can prevent or reduce the tendency for vessel restenosis after an angioplasty leading to shrinkage of the lumen [2]. Thus, careful material selection is required that allow it to expand narrowed vessels permitting the natural flow of fluids to perfuse an area of arterial damage and to act as a biological scaffold while maintaining the appropriate mechanical integrity to withstand interfacial shear stress induced by intraluminal blood flow. However, the widely used permanent prosthetic devices have several unfavorable clinical shortcomings when implanted in the human body that prevent them from being deemed as ideal devices. Some of these limitations include: long-term endothelial dysfunction, delayed re-endothelialization, thrombogenicity, permanent physical irritation, chronic inflammatory local reactions, mismatches in mechanical behavior between stented and non-stented vessel areas, inability to adapt to growth in young patients, and importantly non-permissive or disadvantageous characteristics for later surgical revascularization $[3,4]$.

Ideally, once a stent is implanted within a vessel, the walls of the stents become lined with endothelial cells preventing thrombosis, and after approximately 6-12 months, arterial remodeling and healing is achieved [3]. After healthy arterial healing and remodeling has been accomplished, there is no longer a functional need for the stent. Recognizing such an idea, the development of biodegradable stents that can degrade once the objectives of permanent stents have been fulfilled is currently being explored [2,4-6]. Although, there are very few metallic materials that can fulfill such physiological criteria; magnesium and its alloys possess the ability to degrade once implanted and minimalize adverse biological effects.

In this study, the mechanical properties and tensile failure mechanism of two novel biodegradable alloys for endovascular medical applications $\mathrm{Mg}-\mathrm{Zn}-\mathrm{Se}$ and $\mathrm{Mg}-\mathrm{Zn}-\mathrm{Cu}$ are characterized. The elastic modulus $(\mathrm{E})$ and surface hardness $(\mathrm{H})$ for both the bare alloys and the air formed oxide layer were characterized by nanoindentation methods. X-ray photoelectron spectroscopy (XPS) was used to determine the chemical composition of the oxide layer. Tensile strength $\left(\sigma_{\max }\right)$, and elongation at failure were determined using traditional tensile testing procedures and the poisson ratio $(v)$ for each alloy was calculated.

Additionally, the fracture mechanisms of the alloys have been investigated by scanning electron microscopy (SEM) and energy-dispersive X-ray spectroscopy (EDS). After carefully examining existing literature, this is the first paper to present these alloy compositions with supporting data and the potential application to serve as endovascular medical devices. 


\section{Materials and Methods}

\subsection{Alloy Manufacturing and Sample Preparation}

The alloy compositions were synthesized using an Arc-melting method in inert Argon gas at ACI Alloys, Inc (CA, USA). Both alloy compositions were composed of weight percent (wt.\%) ratios $(98 / 1 / 1) \mathrm{Mg}-\mathrm{Zn}-\mathrm{X} *$. Materials were cast in a 1 in $\times 1$ in $\times 6$ in mold. Test specimens were cut into ASTM-E8 sub-size specimen dimensions.

Samples were mechanically dry ground to \#1200 grit finish using silicon carbide abrasive paper. Samples were further polished to a $2 \mu \mathrm{m}$ finish using an alumina suspension. After mechanical polishing, samples were cleaned in acetone and rinsed with deionized water and blown dry with nitrogen gas. Materials were stored in a plastic container until further testing.

\subsection{XPS and Nanoindentation Analysis}

\subsubsection{XPS Analysis}

Samples were stored in a sealed plastic container for 4-months to allow an air formed oxide layer to develop on the surface of the polished alloys. The oxide layer composition was characterized using a Physical Electronics 5400 ECSA (XPS) system, with a minimum analysis time of $40 \mathrm{~min}$. A maximum radiation beam intensity of $1100 \mathrm{eV}$ was used for analysis on all samples.

\subsubsection{Nanoindentation Analysis}

Nanoindentation analysis was performed to determine the elastic modulus (E) and surface hardness (H) of both the bare metal alloys and samples with an air formed oxide layer. Testing was conducted using a TI 950 TriboIndenter at the Hysitron Testing Facility (MN, USA). The tests were performed using a diamond Berkovich indenter probe. Test parameters included using the load-controlled feedback mode with a $5 \mathrm{~s}$ linear loading to a peak force of $10 \mathrm{mN}$, a $10 \mathrm{~s}$ hold at peak force, and a $5 \mathrm{~s}$ linear unloading duration. Tests were conducted in accordance with the Oliver-Pharr analysis method with a $5 \times 5$ analysis grid [7]. According to the Oliver-Pharr methodology, nanoindentation tests are performed by applying a force to drive an indenter probe into the surface of a sample and then reducing the force to withdraw a probe. The applied load and indenter displacement into the sample are continuously monitored. After experimentation, a load vs. displacement curve was generated from collected data, allowing for the calculation of sample hardness $(H)$ and elastic modulus (E). Indentation testing was performed on the samples after the 4-month aging duration to determine the mechanical properties of the oxide layer. Later, the oxide layer was removed from the samples by mechanically polishing the surface of the alloys and indentation measurements were gathered to determine $(\mathrm{E})$ and $(\mathrm{H})$ of the bare metal samples. 


\subsubsection{Material Density Calculation}

The density of each experimental alloy composition was determined using Archimedes principle as shown in Equation 1. Distilled water was used as the liquid for testing with a density of $1.0 \mathrm{~g} \cdot \mathrm{cm}^{-3}$ $\left(\rho_{\mathrm{w}}\right) . W$ is the weight of the object, and $W_{\mathrm{a}}$ is the apparent weight of the object in water.

$$
\rho=\left(\frac{W}{W-W a}\right) \rho_{w}
$$

\subsection{Tensile Testing and Fracture Analysis}

\subsubsection{Tensile Testing}

Tensile testing specimens were prepared in accordance with ASTM standard E8 sub-size specimen specifications. Testing was conducted using a MTS Bionix 358.02 servohydraulic test system. Tensile tests were conducted at room temperature with a load cell of $1 \mathrm{kN}$ and a crosshead speed of $0.2 \mathrm{~mm} / \mathrm{min}$. From the stress-strain data curves, $0.2 \%$ offset yield values were determined. Elongation at failure was calculated from actual testing specimens and cross-referenced with data from stress-strain curves using Equation 2, where $\mathrm{L}$ is the final stressed length and $L_{0}$ is the unstressed length. Poisson Ratio $(v)$ values for each alloy composition was calculated from physical measurements of the tensile specimens after testing according to Equation 3. The average gauge length value for all test specimens before testing was $30 \mathrm{~mm}$, with an average width and thickness of $6.3 \mathrm{~mm}$ and $2.1 \mathrm{~mm}$, respectively. Tensile specimens were machined in the long dimension of the 1 in $\times 1$ in $\times 6$ in as-cast bar. Testing in additional directions was not possible due to the casting mold used. Tensile testing was repeated on five samples, and the data is reported as the statistical mean \pm standard deviation (Table 1 ).

$$
\begin{gathered}
\mathcal{E}=\left(L-L_{0}\right) / L \\
v=-\left(\varepsilon_{\text {Strain Lateral })} /\left(\varepsilon_{\text {Strain Axial })}\right.\right.
\end{gathered}
$$

\begin{tabular}{|c|c|c|c|c|c|c|}
\hline $\begin{array}{c}\text { Alloy } \\
\text { composition }\end{array}$ & Method of analysis & $\begin{array}{c}\text { Elastic } \\
\text { modulus } \\
(\mathrm{E})(\mathrm{Gpa})^{*}\end{array}$ & $\begin{array}{c}\text { Surface } \\
\text { hardness (H) } \\
(\text { Gpa) * }\end{array}$ & $\begin{array}{l}\text { Elastic modulus } \\
\text { of oxide layer } \\
\text { (E) (Gpa) }\end{array}$ & $\begin{array}{c}\text { Surface } \\
\text { hardness of } \\
\text { oxide layer } \\
\text { (H) (Gpa) }\end{array}$ & $\begin{array}{c}\text { Density ( } \rho) \\
\left(\mathrm{g} \cdot \mathrm{cm}^{-3}\right)\end{array}$ \\
\hline $\mathrm{Mg}-\mathrm{Zn}-\mathrm{Se}$ & Nanoindentation & $38 \pm 4^{a}$ & $0.69 \pm 0.07^{\mathrm{a}}$ & $55 \pm 9^{a}$ & $1.2 \pm 0.3^{\mathrm{a}}$ & $1.75^{\mathrm{b}}$ \\
\hline $\mathrm{Mg}-\mathrm{Zn}-\mathrm{Cu}$ & Nanoindentation & $41 \pm 3^{a}$ & $0.62 \pm 0.07^{\mathrm{a}}$ & $60 \pm 13^{a}$ & $1.3 \pm 0.3^{\mathrm{a}}$ & $1.76^{\mathrm{b}}$ \\
\hline $\mathrm{Mg}-\mathrm{Zn}-\mathrm{Se}$ & Stress-Strain Curve & $11 \pm 6^{\mathrm{b}}$ & - & - & - & - \\
\hline $\mathrm{Mg}-\mathrm{Zn}-\mathrm{Cu}$ & Stress-Strain Curve & $11 \pm 1^{b}$ & - & - & - & - \\
\hline
\end{tabular}

Table 1. Mechanical properties of ternary magnesium alloys.

* Data is represented as mean \pm standard deviation; ${ }^{\mathrm{a}} n=25,{ }^{\mathrm{b}} n=5$. 
2.3.2. Fracture Analysis by Scanning Electron Microscopy and Energy Dispersive $\mathrm{X}$-Ray Spectroscopy

The fractured surfaces were examined after tensile testing. The fractured surfaces were characterized using a JEOL JSM 5900 LV (SEM) and EDS-UTW Detector system (EDS). Images were analyzed in both secondary electron imaging (SEI) and backscatter imaging (BEI) modes at an accelerating voltage of $20 \mathrm{keV}$.

\section{Results}

\subsection{Mechanical Properties of Bare Alloys and Air Formed Oxide Layer Using Nanoindentation}

Table 1 summarizes the mechanical properties of the bare magnesium alloys and the air formed oxide layer. The bare $\mathrm{Mg}-\mathrm{Zn}-\mathrm{Se}$ alloy had a lower elastic modulus than $\mathrm{Mg}-\mathrm{Zn}-\mathrm{Cu}$. Notably, the air formed oxide layers on both $\mathrm{Mg}-\mathrm{Zn}-\mathrm{Se}$ and $\mathrm{Mg}-\mathrm{Zn}-\mathrm{Cu}$ were revealed to possess higher $(\mathrm{E})$ and $(\mathrm{H})$ values than bare metal alloys. Reported oxide layer $(\mathrm{H})$ values nearly doubled when compared with bare metal $(\mathrm{H})$ values for both alloy compositions.

SEM imaging confirmed the formation of an oxide layer on the $\mathrm{Mg}-\mathrm{Zn}-\mathrm{Se}$ alloy. Backscatter imaging revealed the presence of different regions of contrast within the air formed oxide layer (Figure 1C). After mechanical polishing, backscatter imaging of the alloy did not reveal any separable phases as seen in the oxide layer prior to polishing (Figure 1D). XPS analysis of the oxide layer determined significant deposition of magnesium (15.2\%), oxygen (35.5\%), and carbon (40.9\%) which would readily form $\mathrm{MgO}, \mathrm{Mg}(\mathrm{OH})_{2}$ and $\mathrm{MgCO}_{3}$ on the surface of the material (Figure 1). Aluminum $(5.9 \%)$ and nitrogen $(2.5 \%)$ deposits were also identified from the XPS spectrum. The room temperature density of the Mg-Zn-Se material, was determined to be $1.75\left(\mathrm{~g} \cdot \mathrm{cm}^{-3}\right)$ (Table 1$)$.

Figure 1. Scanning electron microscopy (SEM) images and X-ray photoelectron spectroscopy (XPS) analysis of oxide layer formation on the Mg-Zn-Se alloy.

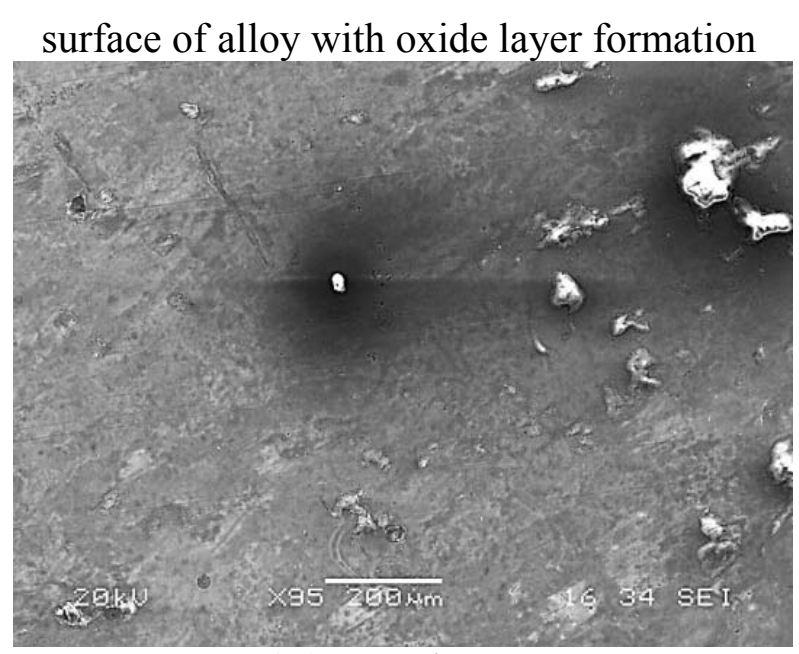

(A) SEM image surface of alloys without oxide layer

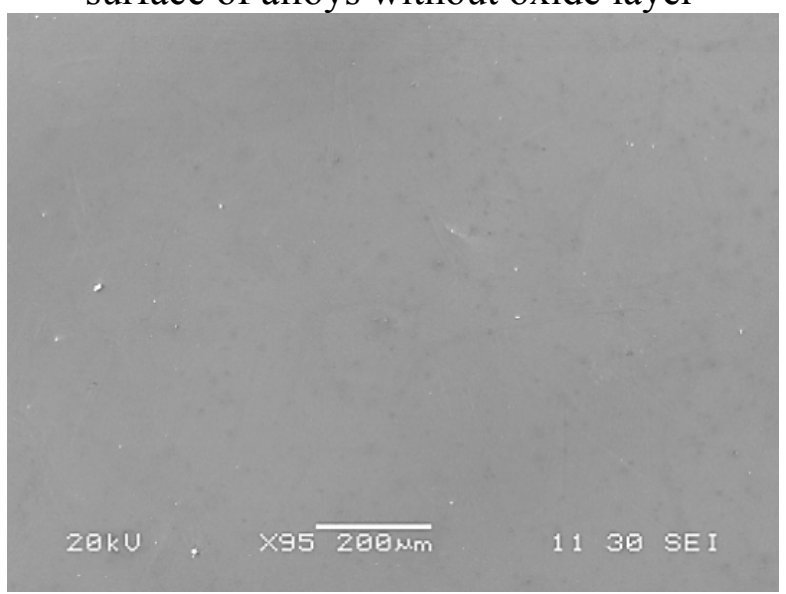

(B) SEM image 
Figure 1. Cont.

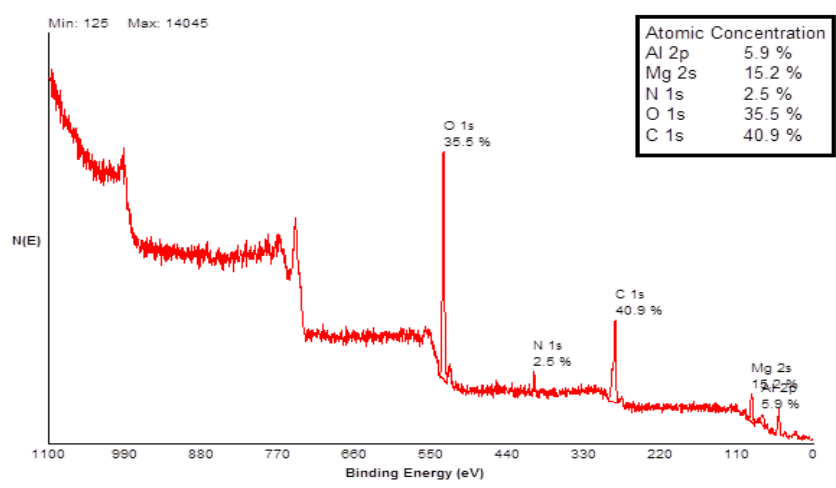

XPS analysis of oxide layer

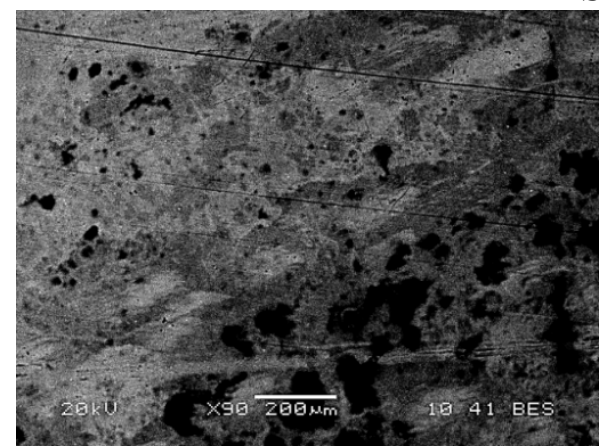

(C) backscatter image

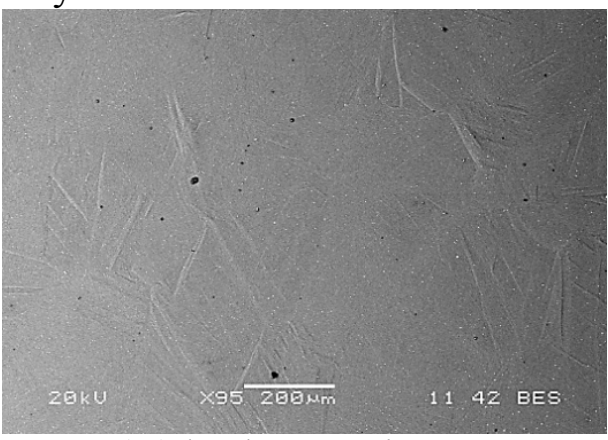

(D) backscatter image

Comparably, SEM imaging confirmed the formation of an oxide layer on the $\mathrm{Mg}-\mathrm{Zn}-\mathrm{Cu}$ alloy. As seen in Figure 2, backscatter imaging revealed different regions of contrast within the air formed oxide layer (Figure 2C). After the abrasive removal of the oxide layer, backscatter imaging of the alloy revealed two separable regions of contrast along the grain boundaries and grains of the material (Figure 2D). XPS analysis of the oxide layer portions showed significant deposition of magnesium (14\%), oxygen (43.6\%), and carbon (33.4\%) (Figure 2). Aluminum (8.8\%) deposits were also detected on the surface of the $\mathrm{Mg}-\mathrm{Zn}-\mathrm{Cu}$ alloy in larger amounts than was detected on the $\mathrm{Mg}-\mathrm{Zn}-\mathrm{Se}$ alloy $(5.9 \% \mathrm{Al})$. The room temperature density of the $\mathrm{Mg}-\mathrm{Zn}-\mathrm{Cu}$ material, was determined to be $1.76 \mathrm{~g} \cdot \mathrm{cm}^{-3}$ (Table 1).

Figure 2. SEM images and XPS analysis of oxide layer formation on the $\mathrm{Mg}-\mathrm{Zn}-\mathrm{Cu}$ alloy.

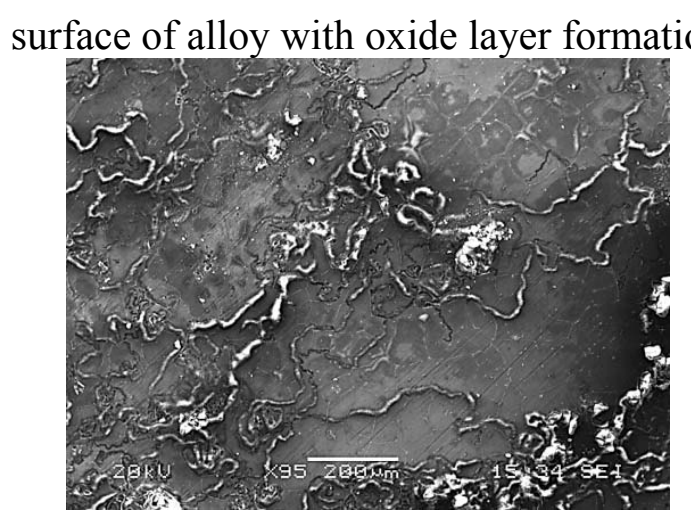

(A) SEM image

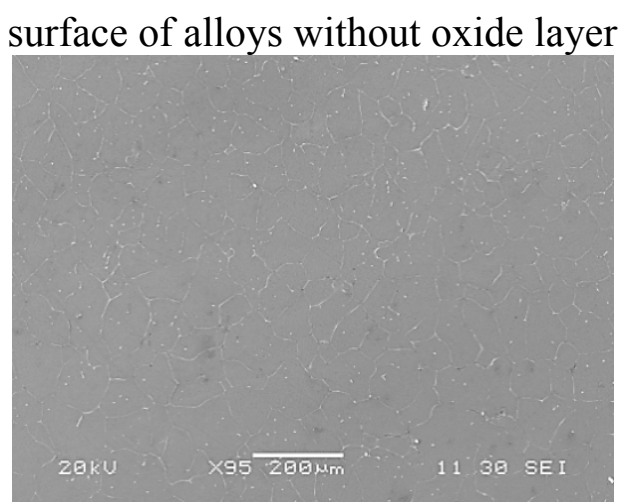

(B) SEM image 
Figure 2. Cont.
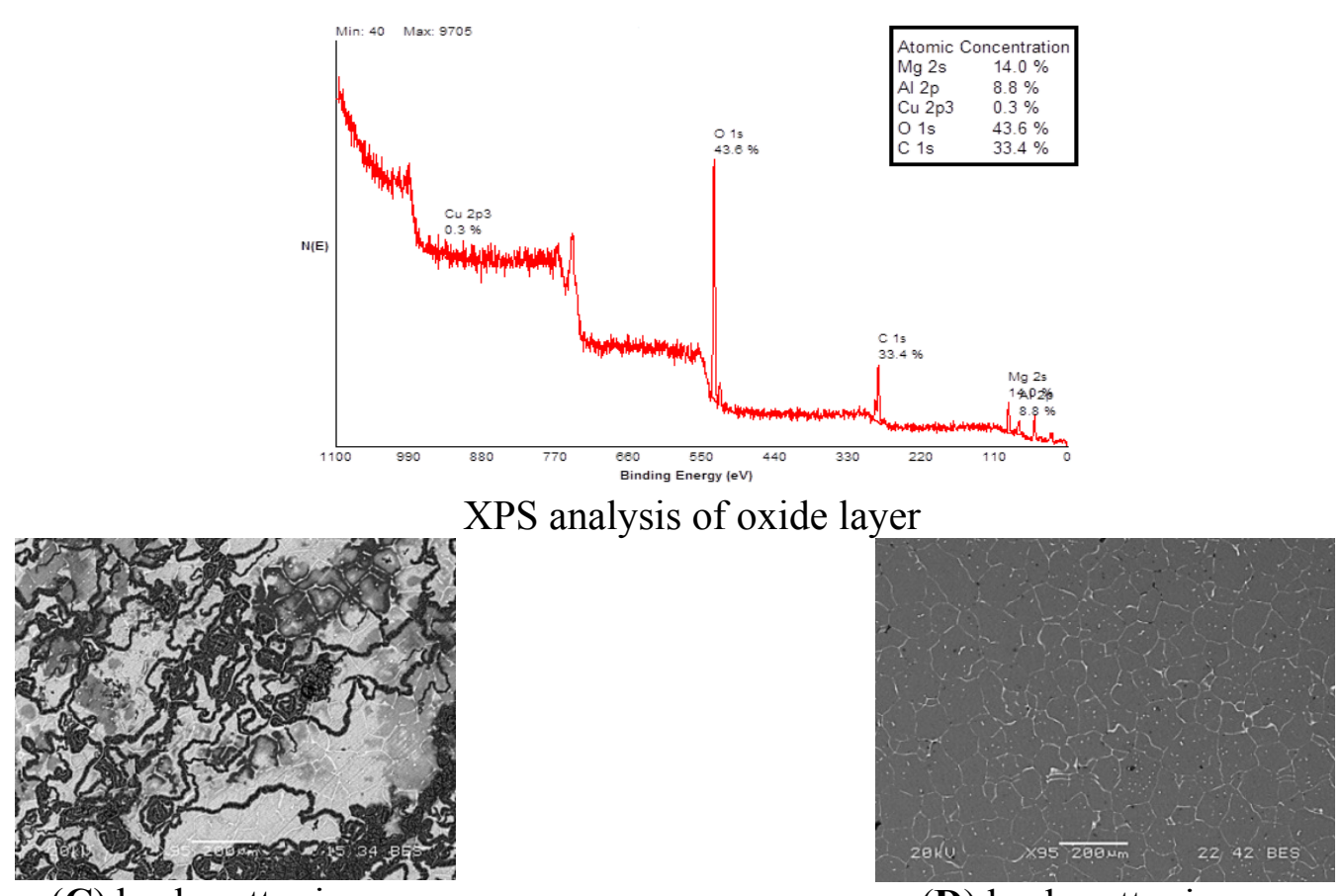

(C) backscatter image

(D) backscatter image

\subsection{Evaluation of Mechanical Properties}

Table 2 summarizes the tensile properties of the $\mathrm{Mg}-\mathrm{Zn}-\mathrm{Cu}$ and $\mathrm{Mg}-\mathrm{Zn}-\mathrm{Se}$ alloys compared to materials that are widely used for endovascular biomedical applications.

Table 2. Tensile properties of ternary magnesium alloys at room temperature $\left(25^{\circ} \mathrm{C}\right)$.

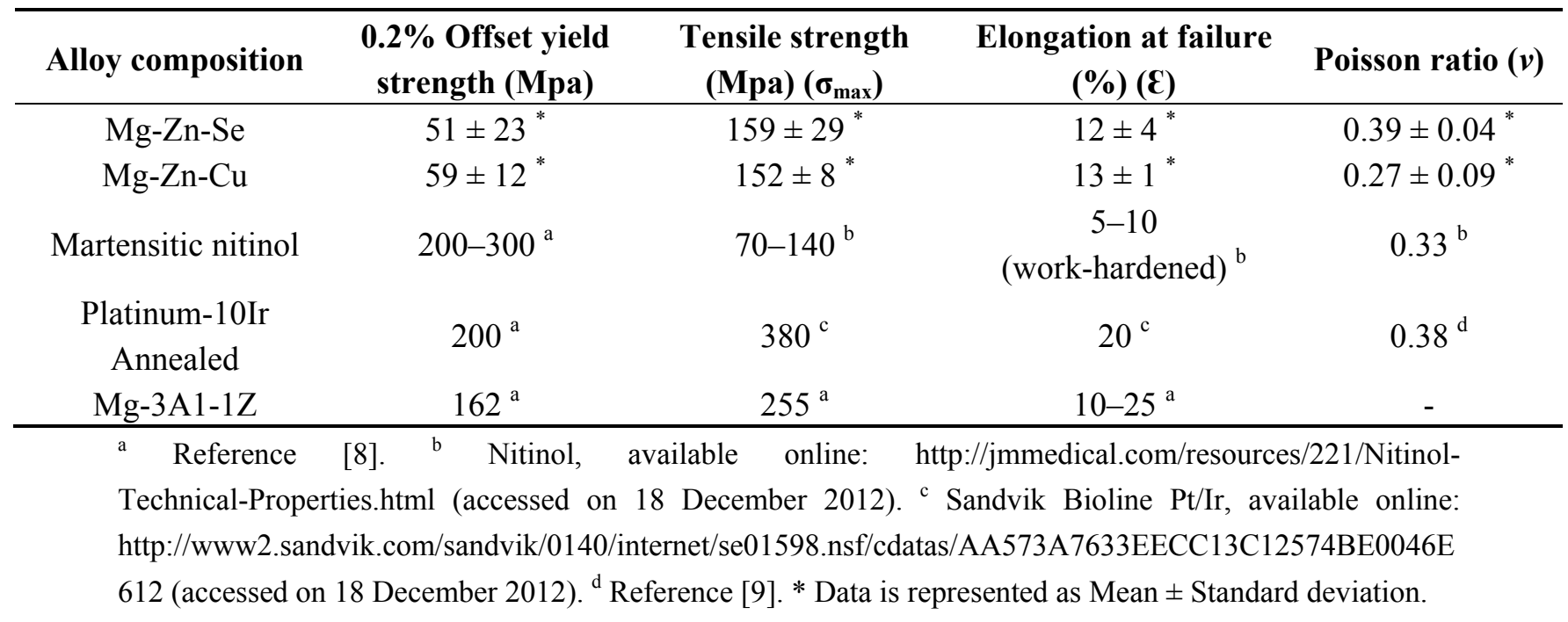

Both $\mathrm{Mg}-\mathrm{Zn}-\mathrm{Se}$ and $\mathrm{Mg}-\mathrm{Zn}-\mathrm{Cu}$ alloys possess similar mean tensile strength values ranging from 152-159 MPa. Offset yield strength $(0.2 \%)$ for both $\mathrm{Mg}-\mathrm{Zn}-\mathrm{Cu}$ and $\mathrm{Mg}-\mathrm{Zn}-\mathrm{Se}$ was lower than martensitic Nitinol, Pt-10Ir, and Mg-3A1-1Z. Notably, Mg-Zn-Cu had a higher elongation at failure than Mg-Zn-Se, work-hardened martensitic Nitinol, and had a comparable value to Mg-3A1-1Z. $\mathrm{Mg}-\mathrm{Zn}-\mathrm{Cu}$ was revealed to possess a lower (v) of 0.27 while $\mathrm{Mg}-\mathrm{Zn}-\mathrm{Se}$ had a (v) of 0.39 which is 
comparable to that of annealed Pt-10Ir. Nanoindentation testing showed the $\mathrm{Mg}-\mathrm{Zn}-\mathrm{Se}$ and $\mathrm{Mg}-\mathrm{Zn}-\mathrm{Cu}$ alloys to possess a mean elastic modulus $38 \mathrm{GPa}$ and $41 \mathrm{GPa}$, respectively. Stress-strain curve analysis, revealed $\mathrm{Mg}-\mathrm{Zn}-\mathrm{Se}$ and $\mathrm{Mg}-\mathrm{Zn}-\mathrm{Cu}$ alloys both to possess an elastic modulus of $11 \mathrm{GPa}$. Thus, comparable tensile strength, higher elongation at failure values, reduced elastic modulus values for both nanoindentation and MTS testing, and poisson ratio values similar to materials currently used for endovascular applications indicates the potential use of $\mathrm{Mg}-\mathrm{Zn}-\mathrm{Se}$ and $\mathrm{Mg}-\mathrm{Zn}-\mathrm{Cu}$ alloys for endovascular biomedical applications.

\subsection{Fracture Analysis}

The Mg-Zn-Se alloy predominantly failed by transgranular fracture, while the $\mathrm{Mg}-\mathrm{Zn}-\mathrm{Cu}$ alloy failed by intergranular fracture. SEM images of the fractured surfaces for both alloys are shown in Figure 3. Mg-Zn-Se transgranular brittle fractured surfaces can be seen in Figure 3A-D, which are characterized by smooth faced fractured surfaces. Intergranular failure of $\mathrm{Mg}-\mathrm{Zn}-\mathrm{Cu}$ can be seen in Figure $3 \mathrm{E}-\mathrm{H}$, characterized by fracture along adjacent grain facets. Tensile specimens for both alloys revealed to be moderately ductile with characteristic fibrous and shear portions (Figure 4). Fractured $\mathrm{Mg}-\mathrm{Zn}-\mathrm{Cu}$ specimens also showed slight cup-cone behavior (Figure 4B). Further SEM analysis on fractured $\mathrm{Mg}-\mathrm{Zn}-\mathrm{Cu}$ samples showed an increased concentration of $\mathrm{Cu}$ primarily observed along the grain boundaries of the material and on portions of the grain as seen in Figure 5A,B. Cu deposits are identified as whitened phases within the image. EDS analyses on the white deposits highlight $\mathrm{Cu}$ concentrations as high as $32 \mathrm{wt} . \%$ (Figure $5 \mathrm{~A}$ ).

Figure 3. Comparative SEM fracture surface images for magnesium alloys after normal tensile failure.

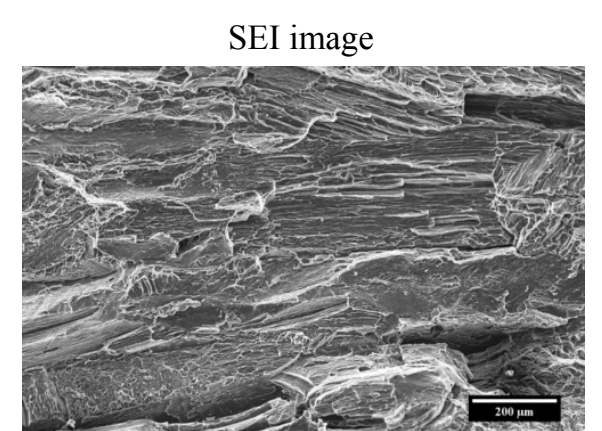

(A)

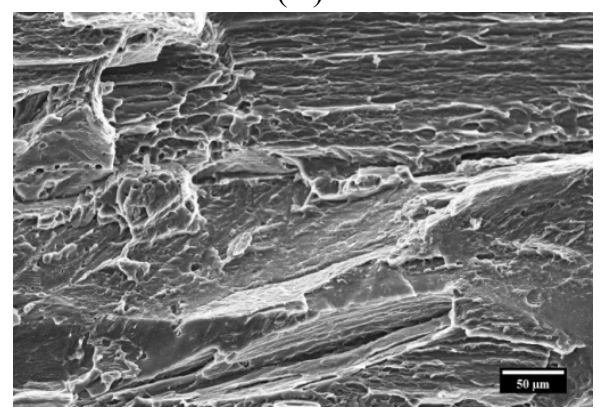

(C)
Mg-Zn-Se

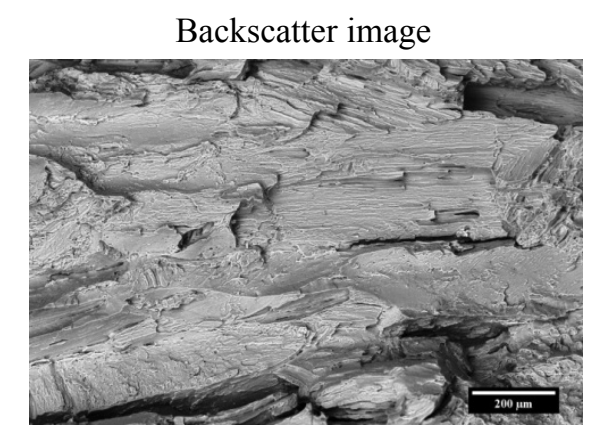

(B)

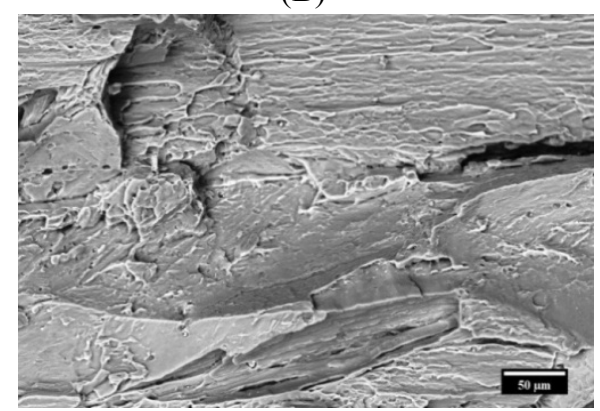

(D) 
Figure 3. Cont.

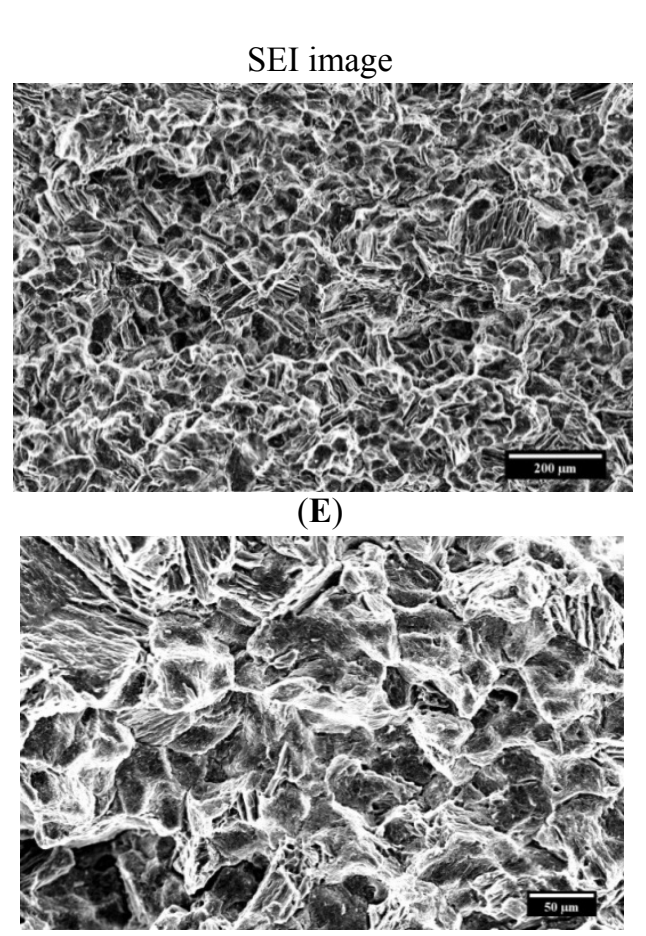

(G)

\section{Mg-Zn-Cu}

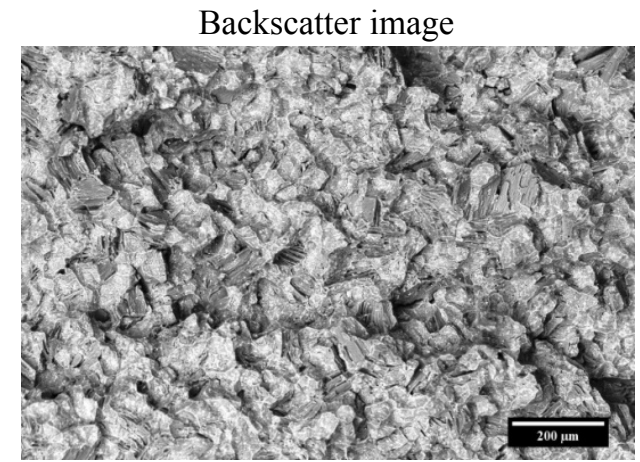

(F)

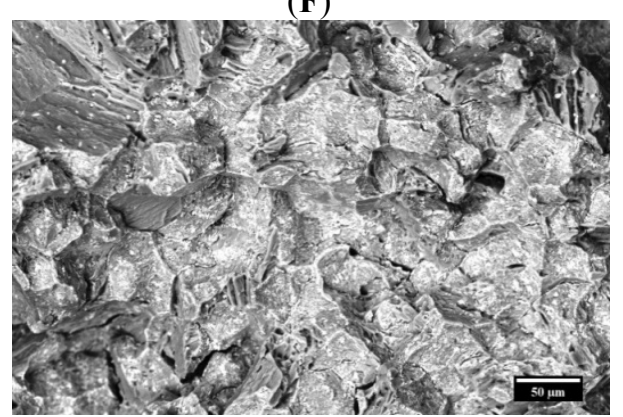

(H)

Figure 4. Optical images of tensile specimens after fracture. (A) Mg-Zn-Se alloy with transgranular brittle failure; (B) $\mathrm{Mg}-\mathrm{Zn}-\mathrm{Cu}$ alloy with intergranular failure with an average $13 \%$ elongation.

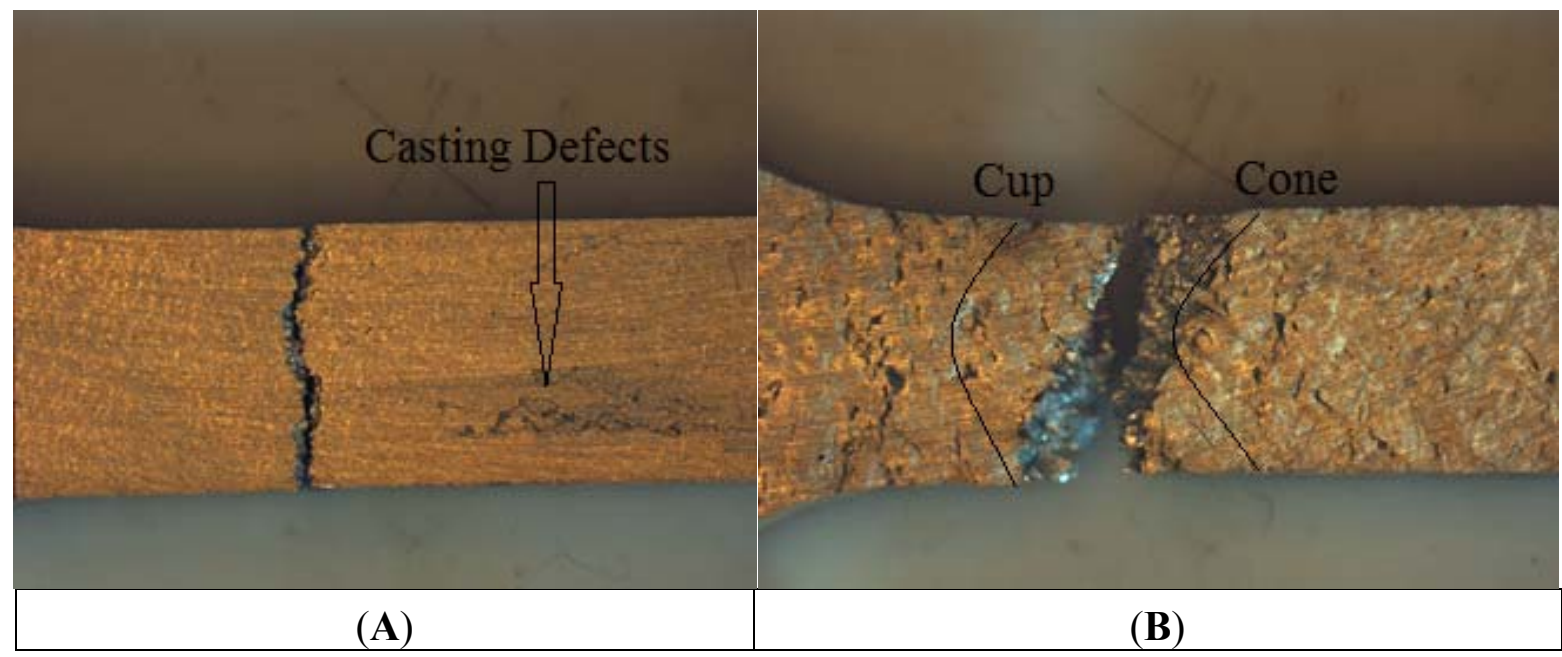

Analysis of the $\mathrm{Mg}-\mathrm{Zn}-\mathrm{Se}$ and the $\mathrm{Mg}-\mathrm{Zn}-\mathrm{Cu}$ alloy tensile specimens that did not show the same tensile behavior as average tensile specimens, failed primarily due to casting defects. SEM analysis on such fractured surfaces confirmed material deformations within the matrix of the alloy tensile specimens. Such deformations indicate potential flaws formed during the manufacturing of the materials as well as being a result from elemental interactions within the material between $\mathrm{Mg}, \mathrm{Zn}$ and $\mathrm{Se} / \mathrm{Cu}$. 
Figure 5. $\mathrm{Mg}-\mathrm{Zn}-\mathrm{Cu}$ alloy with normal failure showing $\mathrm{Cu}$ along boundaries of failure.

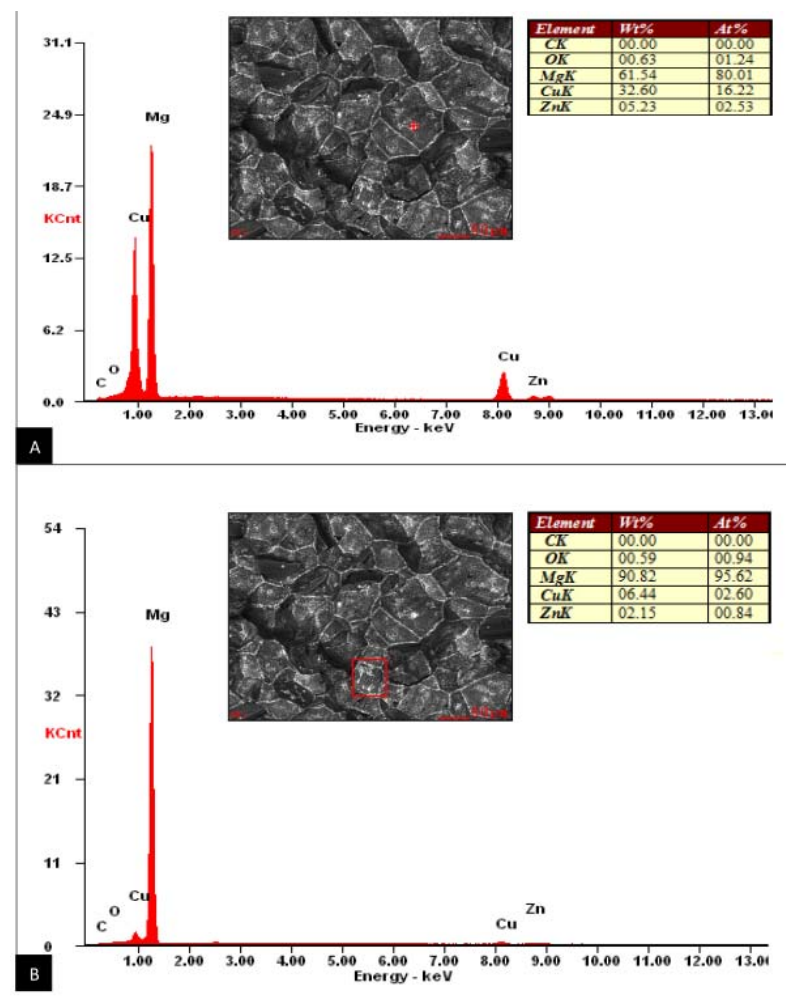

Deformations within the Mg-Zn-Se tensile specimen can be seen in Figure 6. Backscatter SEM images clearly show the deformation as a separate phase from the bulk material of Magnesium (Figure 6A,B). EDS analysis identified the darkened phase to consist of an elemental ratio with 29 wt.\% of oxygen, which is consistent with a likely formation of $\mathrm{MgO}$. (Figure 6C).

Figure 6. $\mathrm{Mg}-\mathrm{Zn}-\mathrm{Se}$ alloy casting defect in tensile specimen leading to premature failure.

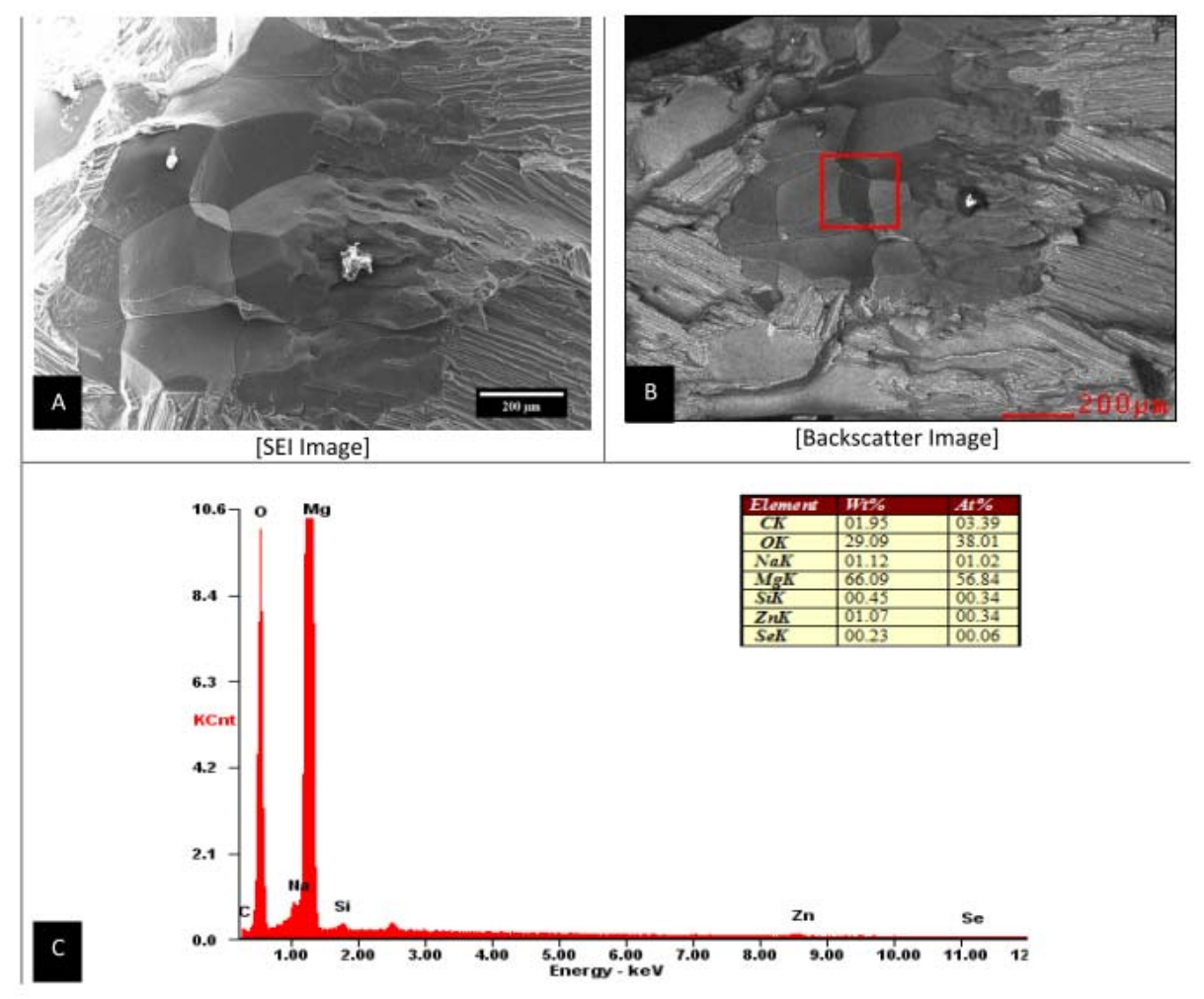


Prematurely failed $\mathrm{Mg}-\mathrm{Zn}-\mathrm{Cu}$ specimens reveal a similar type of deformation as was seen in the $\mathrm{Mg}-\mathrm{Zn}$-Se specimen. Backscatter SEM analysis showed the deformed portion from the remaining alloy material (Figure 7B). Shear failure is evident from the smoothened surface of the material in this deformed portion, as compared to the regular intergranular failure for the specimen. EDS analysis revealed the deformed region to be composed mostly of magnesium with lower amounts of oxygen and copper (Figure 7C).

Figure 7. $\mathrm{Mg}-\mathrm{Zn}-\mathrm{Cu}$ alloy casting defect in tensile specimen leading to premature failure.

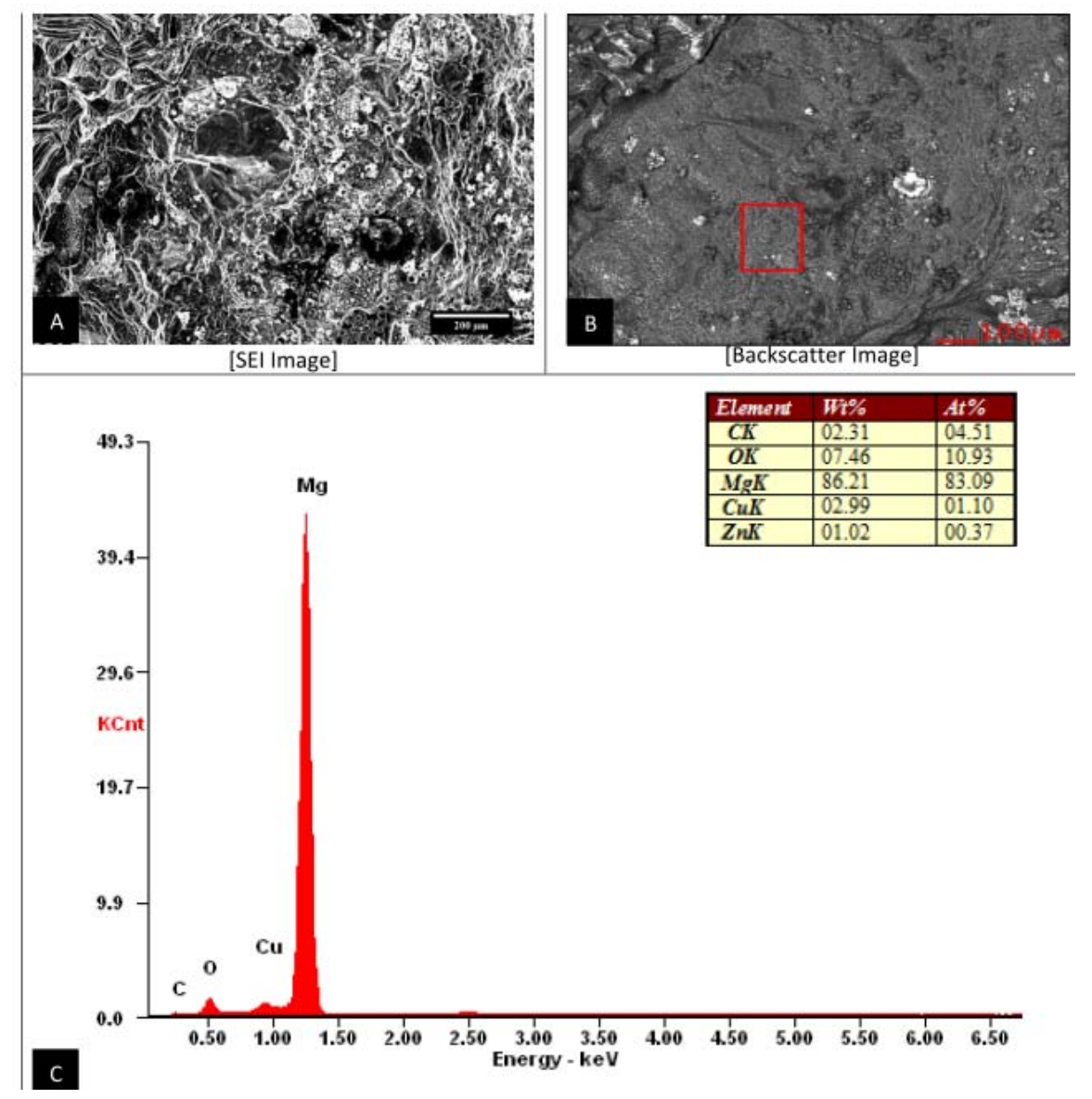

\section{Discussion}

In this paper, the mechanical properties of novel bio-absorbable materials $\mathrm{Mg}-\mathrm{Zn}-\mathrm{Cu}$ and $\mathrm{Mg}-\mathrm{Zn}-\mathrm{Se}$ for endovascular medical device applications are investigated. The composition of these alloys is shown in Table 3. After comparing the mechanical properties of $\mathrm{Mg}-\mathrm{Zn}-\mathrm{Cu}$ and $\mathrm{Mg}-\mathrm{Zn}-\mathrm{Se}$ alloys to conventionally used materials for endovascular applications such as Nitinol, Pt-10Ir, and magnesium alloys Mg-3A1-1Z, it is evident that these materials possess the qualities suitable for the manufacturing of endovascular medical devices. Both Nitinol and Pt-10Ir alloys possess the elasticity required to conform to vessel geometry and have a high corrosion resistance to serve as permanent implants; while the Mg-3Al-1Z alloy has the appropriate ductility and a reduced corrosion rate to serve as a scaffold for desired wound healing to occur [8]. Immediately, the density of the $\mathrm{Mg}-\mathrm{Zn}-\mathrm{Se}$ and $\mathrm{Mg}-\mathrm{Zn}-\mathrm{Cu}$ material are very close in value to the density of Magnesium $\left(1.738 \mathrm{~g} \cdot \mathrm{cm}^{-3}\right)$, with values of 1.75 and $1.76 \mathrm{~g} \cdot \mathrm{cm}^{-3}$ respectively [10]. The increased density for the tested alloys in $\mathrm{Mg}-\mathrm{Zn}-\mathrm{Se}$ and 
$\mathrm{Mg}-\mathrm{Zn}-\mathrm{Cu}$ indicate that these alloys possess a higher strength to weight ratio and are more favorable to withstand compressive arterial wall stresses in the application of stents than that of pure magnesium stents. More notably, the $\mathrm{Mg}-\mathrm{Zn}-\mathrm{Se}$ alloy possesses a density nearly identical to that of a $\mathrm{Mg}$ reinforced alloy with $1.5 \mathrm{wt} . \% \mathrm{Al}_{2} \mathrm{O}_{3}\left(1.756 \mathrm{~g} \cdot \mathrm{cm}^{-3}\right)$ which is currently being explored for stent device applications because of its more favorable strength to weight ratio [10].

Table 3. Composition of ternary magnesium alloys.

\begin{tabular}{ccccc}
\hline Alloy composition & Wt.\% Mg & Wt.\% Zn & Wt.\% Cu (X *) & Wt.\% Se (X *) \\
\hline Mg-Zn-Se (98/1/1) & 98 & 1 & - & 1 \\
$\mathrm{Mg}-\mathrm{Zn}-\mathrm{Cu}(98 / 1 / 1)$ & 98 & 1 & 1 & - \\
\hline
\end{tabular}

The $0.2 \%$ offset values for $\mathrm{Mg}-\mathrm{Zn}-\mathrm{Se}$ and $\mathrm{Mg}-\mathrm{Zn}-\mathrm{Cu}$ were notably lower than any of the values for martensitic Nitinol, Annealed Platinum-10Ir, or the Mg-3A1-1Z alloy. The lower yield strength at the $0.2 \%$ offset compared to the other Nitinol, platinum, and magnesium alloys show that the Mg-Zn-Se and $\mathrm{Mg}-\mathrm{Zn}-\mathrm{Cu}$ alloys are more readily permanently deformed by an applied stress when compared to the other aforementioned materials currently used for medical devices. However, the ultimate tensile strength for the Mg-Zn-Se (159 MPa) and Mg-Zn-Cu (152 MPa) alloys obtained from observed stress-strain behavior was higher before material fracture than martensitic Nitinol $(70-140 \mathrm{MPa})$ as seen in Figure 8.

Figure 8. Stress-strain behavior from tensile testing of $\mathrm{Mg}-\mathrm{Zn}-\mathrm{Cu}$ and $\mathrm{Mg}-\mathrm{Zn}-\mathrm{Se}$ alloys compared to martensitic nitinol. (A) Room temperature tensile stress-strain response of the Mg-Zn-Se alloy; (B) Quasi-static, room temperature tensile stress-strain response of the martensitic Nitinol alloy [11]. (C) Room temperature tensile stress-strain response of the $\mathrm{Mg}-\mathrm{Zn}-\mathrm{Cu}$ Alloy.

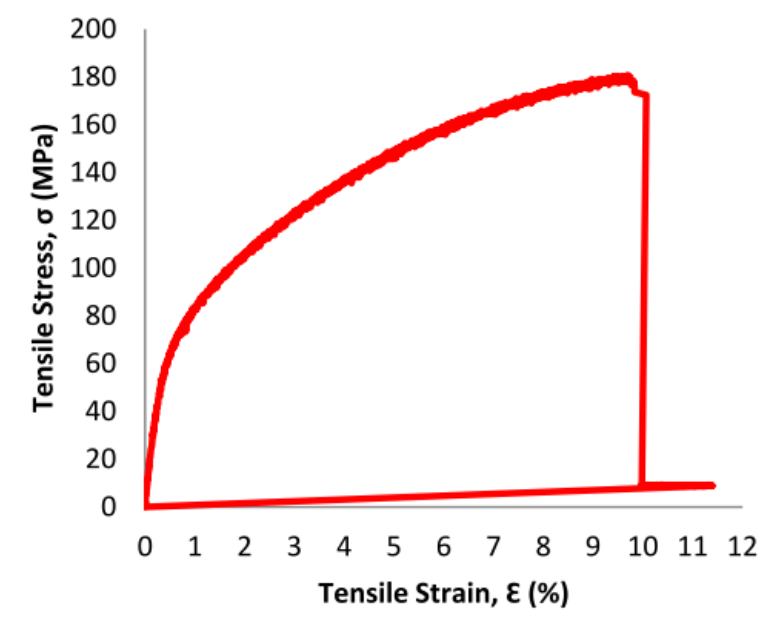

(A)

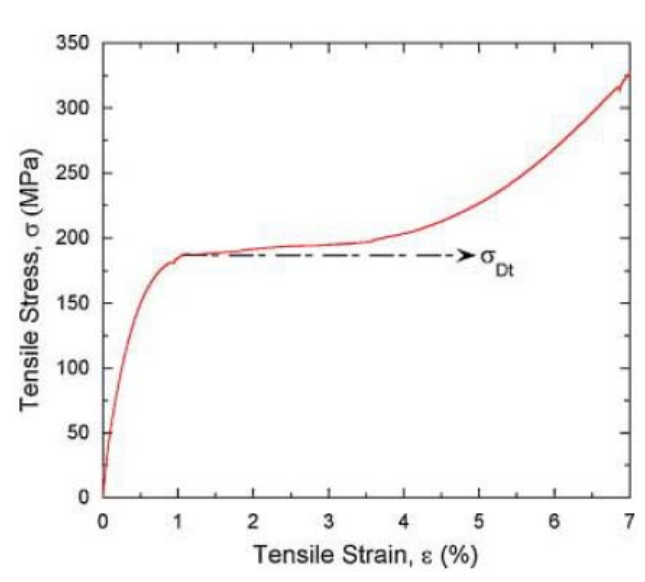

(B) 
Figure 8. Cont.

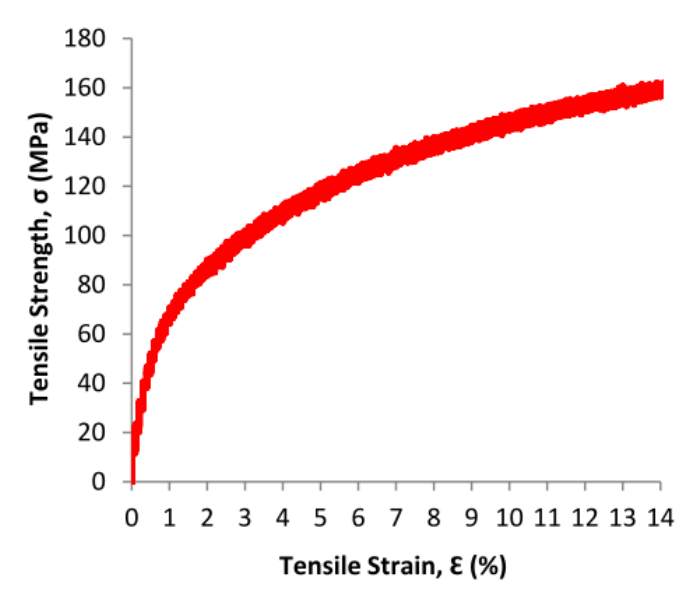

(C)

This suggests, that these $\mathrm{Mg}-\mathrm{Zn}-\mathrm{Se}$ and $\mathrm{Mg}-\mathrm{Zn}-\mathrm{Cu}$ alloys retain their strength and are more stable than NiTi alloys which readily undergo transformation shifts between austenitic and martensitic phases at temperatures ranging from -200 to $110{ }^{\circ} \mathrm{C}$ [12]. This stability is a more desirable quality for endovascular devices, as the strength of the NiTi alloys is greatly reduced during phase transformations of the austenite-martensite phase as evident by its yield strength ranging from 70-140 MPa. However, the super elastic shape memory feature of the NiTi alloy remains highly desirable for medical devices.

The surface properties of metallic medical implants are very important to the stability, biocompatibility, and mechanical integrity of the implant [13]. An understanding and analysis of the surface oxide film formed on the metallic material is directly related to the ability of metallic ions to be leached from the surface of the implant. The composition of the surface oxide film changes according to reactions between the surfaces of the metallic materials and living tissues and/or biological fluids, therefore it is important to understand the mechanical properties and elemental composition of the surface oxide formations [14]. In this study, it was shown that the oxide surface layer is primarily composed of oxide coatings most likely including $\mathrm{MgO}, \mathrm{Mg}(\mathrm{OH})_{2}$ and $\mathrm{MgCO}_{3}$. These coatings generally do not release harmful material components into biological tissues or fluids through diffusion, however, the increased basicity of the $\mathrm{Mg}(\mathrm{OH})_{2}$ layer may be unsuitable for cell adhesion and growth under static conditions because of the increased basicity of the immediate physiological environment.

The modulus of elasticity (E) and surface hardness $(\mathrm{H})$ for both the bare $\mathrm{Mg}-\mathrm{Zn}-\mathrm{Se}$ and $\mathrm{Mg}-\mathrm{Zn}-\mathrm{Cu}$ alloys and the oxide layer formed on the surface of the alloys were determined by nanoindentation testing. Generally, the $(\mathrm{E})$ and $(\mathrm{H})$ of the air formed oxide layer were both higher in value than the bare metal alloys for both compositions (Table 2). The higher (E) values for the oxide layers mean that the alloys require more applied stress to deform the materials (strain) than the bare metals. Additionally, the increased (E) of the oxide layers can lead to the development of surface cracks and lead to undesired wear, friction, and material-liquid interfacial interactions [15]. The increase in $(\mathrm{H})$ of the air formed oxide layer offers a comparative idea of the materials resistance to plastic deformation [16]. The $(\mathrm{H})$ values for both the bare metals and oxide layers of $\mathrm{Mg}-\mathrm{Zn}-\mathrm{Cu}$ and $\mathrm{Mg}-\mathrm{Zn}$-Se are significantly lower than $(\mathrm{H})$ values widely explored for shape-memory NiTi binary and ternary alloys with values 
ranging from 1-7 GPa [17]. Given the material properties of the $\mathrm{Mg}-\mathrm{Zn}-\mathrm{Cu}$ and $\mathrm{Mg}-\mathrm{Zn}$-Se alloys, it is understood that these materials should possess the ability to be more compliant to elastic deformation than binary and ternary NiTi alloys because of the higher surface hardness values for NiTi alloys with and without surface treatments when measured by nanoindentation. Persaud-Sharma et al. reported bulk elastic moduli of 32-98 GPa for electro and magneto-electropolished NiTi, NiTiCu, NiTiCr, and NiTiTa alloys with surface hardness values ranging from 1.2 to $6.5 \mathrm{GPa}$ [17]. Comparably, the bulk elastic moduli for the $\mathrm{Mg}-\mathrm{Zn}-\mathrm{Se}$ and $\mathrm{Mg}-\mathrm{Zn}-\mathrm{Cu}$ alloys are $38 \mathrm{GPa}$ and $41 \mathrm{GPa}$ when calculated by nanoindentation methods, respectively. The lower (E) values for the experimental Mg-Zn-Se and $\mathrm{Mg}-\mathrm{Zn}-\mathrm{Cu}$ alloys indicate that they are softer and less stiff than Nitinol materials which are currently used to manufacture endovascular devices.

A difference in elastic modulus values exists for the $\mathrm{Mg}-\mathrm{Zn}-\mathrm{Se}$ and $\mathrm{Mg}-\mathrm{Zn}-\mathrm{Cu}$ alloys when measured by nanoindentation and MTS tensile testing procedures. The (E) values determined by nanoindentation showed to be greater than the (E) values determined from tensile testing by a factor of 4 (Table 2). The first possible explanation for this observed difference in values resulting from the two analytical procedures includes the placement of the indenter tip on a non-homogenous sample. In such a sample, areas of separated elemental phases formed within the alloy may possess different mechanical properties as seen with the $\mathrm{Mg}-\mathrm{Zn}-\mathrm{Cu}$ alloy, which would lead to different $(\mathrm{E})$ and $(\mathrm{H})$ values if the indent measurements are collected on or near the grain boundary. Additionally, nanoindentation tests measure a very small portion of the sample surface, almost at the dimension of a single elemental grain. Thus, if the tested sample is non-homogenous, multiple measurements at different areas across the sample surface $(n>30)$ are needed to characterize bulk properties of the material. Conventional tensile-testing procedures consider the entire alloy system inclusive of its intergranular interactions, whereas the nanonindentation technique is limited by the depth of the indent, probe tip shape, and restrained by the quality of the sample surface finish. Moreover, this observed difference can be explained by the reduced sensitivity of the MTS equipment when compared to that of the nanoindentation system which operates on a more automated system with software filters to separate critically erroneous unloading data from the remaining load-displacement data. This matter has been extensively studied by Stauss et al., who attribute differences in microtensile and nanoindentation values to the different size and microstructural levels that are probed [18].

XPS analysis technique was used to determine the elemental composition of the outer 1-10 nm of the material surface for both $\mathrm{Mg}-\mathrm{Zn}-\mathrm{Se}$ and $\mathrm{Mg}-\mathrm{Zn}-\mathrm{Cu}$ oxide layer formation. $\mathrm{Mg}-\mathrm{Zn}$-Se showed an oxide layer atomic composition of magnesium (15.2\%), oxygen (35.5\%), and carbon (40.9\%) which would readily form $\mathrm{MgO}, \mathrm{Mg}(\mathrm{OH})_{2}$ and $\mathrm{MgCO}_{3}$ on the surface of the material (Figure 1). XPS analysis of $\mathrm{Mg}-\mathrm{Zn}-\mathrm{Cu}$ showed oxide layer portions with significant deposition of magnesium (14\%), oxygen (43.6\%), and carbon (33.4\%) (Figure 2). These are consistent with literature studies on similar magnesium based alloys AZ31 and AZ91, in which XPS analysis revealed the presence of $\mathrm{MgO}$, $\mathrm{Mg}(\mathrm{OH})_{2}$ and $\mathrm{MgCO}_{3}$ on the outer surface of both alloys [19]. It has been concluded that the $5.9 \% \mathrm{Al}$ and $8.8 \% \mathrm{Al}$ found on the surface of the $\mathrm{Mg}-\mathrm{Zn}-\mathrm{Se}$ and $\mathrm{Mg}-\mathrm{Zn}-\mathrm{Cu}$ alloys are a result of the Alumina based polishing paste, which was imbedded within the crevices of the alloys that was not removed during the cleaning process (Figures 1 and 2). The formation of $\mathrm{MgO}, \mathrm{Mg}(\mathrm{OH})_{2}$ and $\mathrm{MgCO}_{3}$ on the outer surface of both alloys characterize the majority of the natural oxide layer formation at $25{ }^{\circ} \mathrm{C}$. Larger amounts of oxygen on the surface of the $\mathrm{Mg}-\mathrm{Zn}-\mathrm{Cu}$ alloy shows that this alloy may be 
susceptible to an increased rate of corrosion by forming pitting sites on its surface as the increased oxygen concentration is a result of electron-transport from the metal being oxidized [20].

The tensile strength of as-cast $\mathrm{Mg}-\mathrm{Zn}-\mathrm{Cu}(152 \mathrm{MPa})$ and $\mathrm{Mg}-\mathrm{Zn}-\mathrm{Se}(159 \mathrm{MPa})$ were lower than annealed Pt-10Ir (380 MPa), and Mg-3A1-1Z (255 MPa), but most comparable to martensitic Nitinol (70-140 MPa). The elongation at failure for $\mathrm{Mg}-\mathrm{Zn}-\mathrm{Cu}(13 \%)$ and $\mathrm{Mg}-\mathrm{Zn}-\mathrm{Se}$ (12\%) were most comparable to the Mg-3A1-1Z (10\%-25\%), but lower than annealed Pt-10Ir (20\%). However, the mean $13 \%$ and $12 \%$ elongation for $\mathrm{Mg}-\mathrm{Zn}-\mathrm{Cu}$ and $\mathrm{Mg}-\mathrm{Zn}-\mathrm{Se}$ are significantly higher than the elongation values for currently available cast magnesium alloys which range from $2 \%-8 \%$ tensile elongation for non-high pressured diecast methods [21]. Previous literature suggests that the relative uniformity of critical surface tension for endovascular devices is a primary determinant for the thrombogenicity of implanted stent materials and that tensile elongation itself does not have a significant effect on surface tension [22]. Thus, the high percentages of elongation for $\mathrm{Mg}-\mathrm{Zn}-\mathrm{Se}$ and $\mathrm{Mg}-\mathrm{Zn}-\mathrm{Cu}$ are likely the result of a uniformly distributed surface tension that would be unlikely to result in a thrombogenic surface once implanted. The poisson ratio ( $v$ ) of $\mathrm{Mg}-\mathrm{Zn}-\mathrm{Se}(0.39)$ and $\mathrm{Mg}-\mathrm{Zn}-\mathrm{Cu}(0.27)$ are comparable to both martensitic Nitinol (0.33) and annealed Pt-10Ir (0.38) (Table 3). The ratio of both $\mathrm{Mg}-\mathrm{Zn}-\mathrm{Se}$ and $\mathrm{Mg}-\mathrm{Zn}-\mathrm{Cu}$ are below the incompressibility limit of 0.5 , thus the materials retain the longitudinal and transverse elastic flexibility [23].

The fracture analysis of the $\mathrm{Mg}-\mathrm{Zn}-\mathrm{Se}$ alloy and the $\mathrm{Mg}-\mathrm{Zn}-\mathrm{Cu}$ alloy was performed visually by SEM imaging and by energy dispersive X-ray spectroscopy (EDS). Analysis revealed that the Mg-Zn-Se alloy failed transgranularly as evident by the smooth faced fractured surfaces (Figure $3 \mathrm{~A}-\mathrm{D}$ ). $\mathrm{Mg}-\mathrm{Zn}-\mathrm{Cu}$ predominantly failed by intergranular failure as seen by the outlined grain structures on the fractured surfaces (Figure $3 \mathrm{E}-\mathrm{H}$ ). The transgranular failure of $\mathrm{Mg}-\mathrm{Zn}-\mathrm{Se}$ is comparable to the transgranular fracture mechanism of the AZ31B alloys which is currently used for stenting devices [24]. This mode of failure indicates that the Mg-Zn-Se alloy is more brittle like the AZ31B alloy. Alternatively, the $\mathrm{Mg}-\mathrm{Zn}-\mathrm{Cu}$ alloy undergoes intergranular failure indicating that it is more ductile, which is a more favorable quality in the medical device forming process. Backscatter imaging revealed no separate phases in the fractured surfaces of the $\mathrm{Mg}-\mathrm{Zn}$-Se alloy, whereas two visibly separate phases were evident for $\mathrm{Mg}-\mathrm{Zn}-\mathrm{Cu}$ alloy (Figure 3F,H). Further EDS analysis on the phases identified them as being primarily composed of $\mathrm{Cu}$ on the faces of the fractured surfaces and along the grain boundaries (Figure 5). This is consistent with Zhiyong et al., who proposed that this accumulation of $\mathrm{Cu}$ along the grain boundary of a high zinc magnesium alloy with copper additions (Mg-10Zn-5Al-0.1Sb) is actually the formation of a new $\mathrm{Mg}_{2} \mathrm{Cu}$ phase. The localization of the thermally stable $\mathrm{Mg}_{2} \mathrm{Cu}$ phase along the grain boundaries can strengthen the alloy by dispersive strengthening through pinning the movement of dislocations and the slip of the $\mathrm{Mg}-\mathrm{Zn}-\mathrm{Cu}$ matrix $[25,26]$. Material manufacturing defects common to occur within the bulk material of the $\mathrm{Mg}-\mathrm{Zn}-\mathrm{Cu}$ and $\mathrm{Mg}-\mathrm{Zn}-\mathrm{Se}$ alloys were apparent in some tensile specimens, which led to premature mechanical failure. $\mathrm{MgO}$ and $\mathrm{Mg}(\mathrm{OH})_{2}$ concentrated regions were detected in $\mathrm{Mg}$ - $\mathrm{Zn}$-Se defective specimens which led to premature tensile failure (Figure 6). This is in accordance with previous literature which found similar oxide formations of $\mathrm{MgO}, \mathrm{Mg}(\mathrm{OH})_{2}$, and $\mathrm{MgCO}_{3}$ within the inner layer of the AZ31 and AZ91 alloy [19]. The casting defect for the $\mathrm{Mg}-\mathrm{Zn}-\mathrm{Cu}$ alloy showed a region with higher concentrations of $\mathrm{MgO}$, but more deplete of $\mathrm{Zn}$ and $\mathrm{Cu}$ as compared to grain boundary concentrations (Figure 7). Regions of such a homogenous magnesium concentration and the depletion 
of $\mathrm{Cu}$ from within the matrix are believed to have led to the deteriorated tensile strength of the $\mathrm{Mg}-\mathrm{Zn}-\mathrm{Cu}$ alloy. The poisson ratio of both alloys are below the incompressibility limit of 0.5 , hence the alloys possess the longitudinal and transverse elastic flexibility required for manufacturing.

\section{Conclusions}

Experimental alloys $\mathrm{Mg}-\mathrm{Zn}-\mathrm{Cu}$ and $\mathrm{Mg}-\mathrm{Zn}$-Se show promise for applications as endovascular medical devices as they possess comparable mechanical properties to Nitinol, Pt-10Ir, and the Mg-3A1-1Z alloy. Both experimental alloys possess air formed oxide layer modulus of elasticity values that were greater than the bulk elastic modulus values. The oxide layers were determined to be composed of $\mathrm{MgO}, \mathrm{Mg}(\mathrm{OH})_{2}$, and $\mathrm{MgCO}_{3}$ as revealed by XPS analysis which could foreshadow wear, friction, structural changes, and surface-liquid interfacial behavior. $\mathrm{Mg}-\mathrm{Zn}-\mathrm{Cu}$ and $\mathrm{Mg}-\mathrm{Zn}-\mathrm{Se}$ favorably showed tensile elongation at failure values of $13 \%$ and $12 \%$, respectively. These values are higher than any currently cited, as-cast magnesium alloys available and can lead to more tolerable material limits when developing and forming the raw material into a functional form. Fracture analysis showed that the $\mathrm{Mg}-\mathrm{Zn}$-Se alloy failed transgranularly, while the $\mathrm{Mg}-\mathrm{Zn}-\mathrm{Cu}$ alloy failed by an intergranular fracture mechanism. EDS analysis showed the localization of a $\mathrm{Mg}_{2} \mathrm{Cu}$ phase along the grain boundaries of the $\mathrm{Mg}-\mathrm{Zn}-\mathrm{Cu}$ alloy. Elevated $\mathrm{MgO}$ formations and depleted $\mathrm{Mg}-\mathrm{Zn}$ and $\mathrm{Mg}-\mathrm{Cu}$ regions characterized the defective regions of the $\mathrm{Mg}-\mathrm{Zn}-\mathrm{Cu}$ alloy which caused premature failure.

\section{Acknowledgements}

This project was developed by Dharam Persaud (PI), who is also a recipient of a grant from the National Brain Aneurysm Foundation which financially supports this project. Dharam Persaud is also supported by NIH Fellowship number NIH/NIGMS R25 GM061347. Dharam Persaud would like to thank Walter McKinley for his operation of the MTS tensile testing equipment, and extend his gratitude to Noah Budiansky for his valuable insight into the preparation of this manuscript.

\section{References}

1. Persaud-Sharma, D.; McGoron, A. Biodegradable magnesium alloys: A review of material development and applications. J. Biomimetics Biomater. Tissue Eng. 2012, 12, 25-39.

2. Saito, S. New horizon of bioabsorbable stent. Catheter Cardiovasc. Interv. 2005, 66, 595-596.

3. Moravej, M.; Mantovani, M. Biodegradable metals for cardiovascular stent application: Interest and new opportunities. Int. J. Mol. Sci. 2011, 12, 4250-4270.

4. Erne, P.; Schier, M.; Resink, T.J. The road to bioabsorbable stents: Reaching clinical reality? Cardiovasc. Intervent. Radiol. 2006, 29, 11-16.

5. Colombo, A.; Karvouni, E. Biodegradable stents: Fulfilling the mission and stepping away. Circulation 2000, 102, 371-373.

6. Peuster, M.; Wohlsein, P.; Brugmann, M.; Ehlerding, M.; Seidler, K.; Fink, C.; Brauer, H.; Fischer, A.; Hausdorf, G. A novel approach to temporary stenting: degradable cardiovascular stents produced from corrodible metal-results 6-18 months after implantation into New Zealand white rabbits. Heart 2001, 86, 563-569. 
7. Oliver, W.C.; Pharr, G.M. An improved technique for determining hardness and elastic modulus using load and displacement sensing indentation experiments. J. Mater. Res. 1992, 7, 1564.

8. Poncin, P.; Proft, J. Stent Tubing: Understanding the Desired Attributes. In Proceedings from the Materials \& Processes for Medical Devices Conference, Anaheim, CA, USA, September 8-10, 2003; ASM International: Material Park, OH, USA, 2003.

9. Merker, J.; Lupton, D.; Topfer, M.; Knake, H. High temperature mechanical properties of the platinum group metals. Platinum Met. Rev. 2001, 45, 74-82.

10. Gupta, M.; Sahron, N.M.L. Magnesium, Magnesium Alloys, and Magnesium Composites: A Guide; John Wiley \& Sons: Hoboken, NJ, USA, 2011; Volume 1, pp. 120-150.

11. Niraj, N.; Buravalla, V.; Ramamurty, U. Effect of mechanical cycling on the stress-strain response of a martensitic Notinol shape memory alloy. Mater. Sci. Eng. A 2009, 525, 60-67.

12. Johnson Matthey Medical Components. Nitinol Technical Properties. Available online: http://jmmedical.com/resources/221/Nitinol-Technical-Properties.html\#nitinoltransformation-properties (accessed on 29 November 2012).

13. Kasemo, B.; Lausmaa, J. Surface science aspects on inorganic biomaterials. Crit. Rev. Biocompat. 1986, 2, 335-330.

14. Manivasagam, G.; Dhinasekaran, D.; Rajamanickam, A. Biomedical implants: Corrosion and its prevention-a review. Recent Pat. Corros. Sci. 2010, 2, 40-54.

15. Persson, D.H.E.; Jacobson, S.; Hogmark, S. The influence of phase transformations and oxidation on the galling resistance and low friction behavior of laser processed Co-based alloy. Wear 2003, 254, 1134-1140.

16. Meyers, M.; Chawla, K. Mechanical Behaviors of Materials, 2nd ed; Cambridge University Press : New York, NY, USA, 1999; pp. 162-168.

17. Persaud-Sharma, D.; Munroe, N.; McGoron, A. Electro and magneto-electropolished surface micro-patterning on binary and ternary Nitinol. Trends Biomater. Artif. Organs. 2012, 26, 74-85.

18. Stauss, S.; Schwaller, P.; Bucaille, J.-L.; Rabe, R.; Rohr, L.; Michler, J.; Blank, E. Determining the stress-strain behavior of small devices by nanoindentation in combination with inverse methods. Microelectron. Eng. 2003, 67-68, 818-825.

19. Wang, L.; Shinohara, T.; Zhang, B.P. XPS study of the surface chemistry on AZ31and AZ91 magnesium alloys in dilute $\mathrm{NaCl}$ solution. Appl. Surf. Sci. 2010, 256, 5807-5812.

20. Revie, R.W.; Uhlig, H.H. Corrosion and Corrosion Control: An Introduction to Corrosion Science and Engineering; John Wiley and Sons: Hoboken, NJ, USA, 2008; Volume 4, pp. $125-165$.

21. Grote, K.H.; Antonsson, E. Handbook of Mechanical Engineering; Springer: New York, NY, USA, 2010; Volume 10, pp. 530-540.

22. Shrivastava, S. Medical Device Materials. In Proceedings from the Materials \& Processes for Medical Devices Conference, Anaheim, CA, USA, September 8-10, 2003; ASM International: Material Park, OH, USA, 2003; pp. 69-74.

23. Liu, B.; Zhang, L.; Gao, H. Poisson ratio can play an important role in mechanical properties of biocomposites. Mech. Mater. 2006, 38, 1128-1142.

24. Zhang, H.; Wang, W.; Wei, Y.; Li, J.; Wang, J. Fatigue fracture mechanism of AZ31B magnesium alloy and its welded joint. Trans. Nonferrous Met. Soc. China 2011, 21, 1225-1233. 
25. Zhiyong, Y.; Yuhua, Z.; Weili, C.; Jinshan, Z.; Yinghui, W. Effect of $\mathrm{Cu}$ addition on microstructure and properties of Mg-10Zn-5Al-0.1Sb high zinc magnesium alloy. China Foundry 2012, 9, 43-47.

26. Chen, Z. Heat-Resistant Magnesium Alloy; Chemical Industry Press: Beijing, China, 2006; 109-115.

(C) 2013 by the authors; licensee MDPI, Basel, Switzerland. This article is an open access article distributed under the terms and conditions of the Creative Commons Attribution license (http://creativecommons.org/licenses/by/3.0/). 